\title{
Why Do We Need Algorithmic Historiography?
}

\author{
Eugene Garfield \\ Institute for Scientific Information, 3501 Market Street, Philadelphia, PA 19104. \\ E-mail: Garfield@codex.cis.upenn.edu
}

\section{A. I. Pudovkin}

Institute of Marine Biology, Russian Academy of Sciences, Vladivostok 690041, Russia.

E-mail: aipud@online.ru

\author{
V. S. Istomin \\ Center for Teaching, Learning, and Technology, Washington State University, Pullman, WA 99164-4550. \\ E-mail:Vi@mail.wsu.edu
}

\begin{abstract}
This article discusses the rationale for creating historiographs of scholarly topics using a new program called HistCite $^{\mathrm{TM}}$, which produces a variety of analyses to aid the historian identify key events (papers), people (authors), and journals in a field. By creating a genealogic profile of the evolution, the program aids the scholar in evaluating the paradigm involved.
\end{abstract}

\section{Introduction}

The editor of this special issue, Chaomei Chen, asked us to provide an applications-oriented view of algorithmic historiography and how it relates to understanding scientific paradigms. The first public presentations of our system for algorithmic historiography were given at the University of Pittsburgh (Garfield, 2001a) and then at Drexel University (Garfield, 2001b). In addition, a paper by the authors has been presented at the national meeting of the American Society for Information Science and Technology (Garfield, Pudovkin, \& Istomin, 2002).

Of late, it has become fashionable to speak about paradigms, but a paradigm is basically a model of a field. Historiography is intimately related to understanding paradigms shifts. However, we tend to use the term for concepts that are broader in scale than typical literature searches. But if you want to understand how a paradigm has changed, you must identify the literature of the topic first. Then by observing the changes in the citation of key works of that field, you see how the basic concepts or the perception of the paradigm changed.

() 2003 Wiley Periodicals, Inc.
Our historiographic software, hereinafter referred to as HistCite $^{\mathrm{TM}}$, facilitates the understanding of paradigms by enabling the scholar to identify the significant works on a given topic. At the same time it provides a graphic, geneologic presentation of the citational links between them. The system also preserves these citation links for the entire bibliographic collection so that one can explore intermediary links involving less frequently cited works.

The historiography of science can be viewed in a variety of ways. Classical historians of science discuss ancient, medieval, renaissance, and contemporary 19th and 20th century science descriptively. In their narratives and analysis, they also provide extensive bibliographic documentation. Historic scholars are frequently heavy users of library services and usually take great pride in having read both the classical and ancillary, even ephemeral works in the field. In our conception of facilitating historiography-that is, writing the history of modern science-we make the basic assumption that the bibliographic information contained in a collection of published scientific articles is sufficient for the purpose of recapturing the historiographic structure of the field. Because citation indexes utilize the cited works of thousands of authors, it is assumed that collectively they call out the basic works in any field. Gaps may exist in the documentation provided by individual authors, but collectively they produce a fairly complete picture of the historic background of the topic.

Our approach to historiography is decidedly genealogic. We want to show where a particular topic began and identify both the bibliographic antecedents and descendents of its principal, often primordial papers and authors. Once these basic structural elements (papers and books) of the field are identified, they are "summarized" graphically as an 


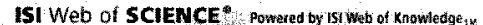

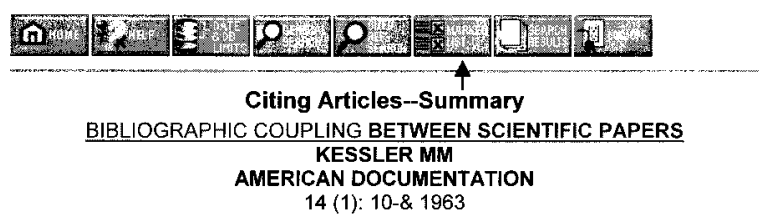

These documents in the database cite the above article

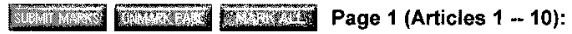

| $\quad[1|\underline{2}| \underline{3}|\underline{4}| \underline{5}|\underline{6}| \underline{z}|\underline{8}| \underline{9} \mid \underline{10}]$ | | |

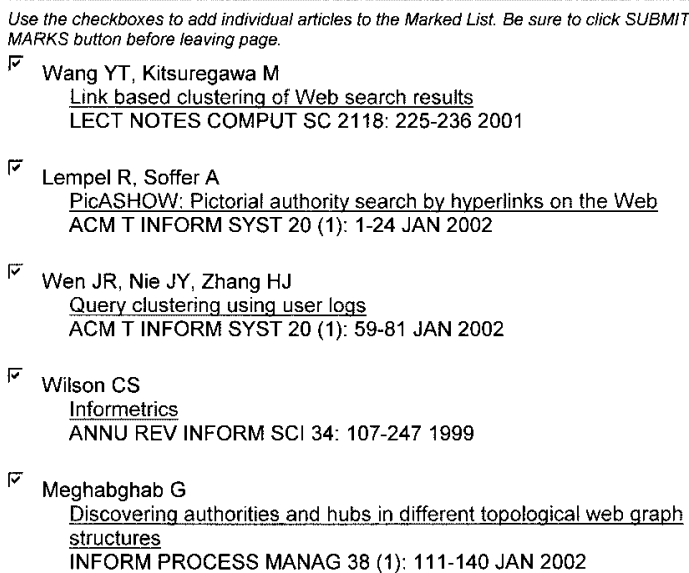

135 of 31000834 documents in the database cite the above article.

Acceptable Use Policy
Copyright $\odot 2002$ Institute for Scien

Copyright $\odot 2002$ Instifute for Scientific Information

FIG. 1. Web of Science cited reference search on MM Kessler 1963.

interconnected historiograph involving, typically, the 5\% that are the most-cited. A chronologic map or flow diagram is created in which the nodes for these works are represented either as circles, ovals, rectangles, or other icons. The

ISIWeb of SCIENCE Powered by Isi wob of Knowledge sw

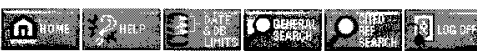

Marked Records

135 Records on the marked list

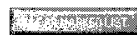

STEP 1: Select sort and output fields for the entire marked list.

\begin{tabular}{l|l} 
Select sort & Select fields to include in addition to the author(s), article title and
\end{tabular}

option:

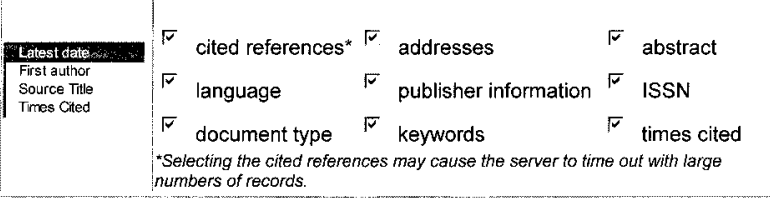

STEP 2: Select action for output.

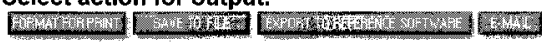

$$
4
$$

Historiographer prototype. Version: 2002.01.24

Use [Browse...] button to select a file with an input set then [Add] to add it to the network. Browse. Add

Caption text for the network set:

End session

To give the program a head start use:

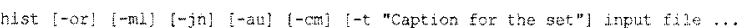

-or to skip "Outer References" module

"nni to skip "Missing Links" module

in to skip "Journal list" module

at to skip "All-Author list" module

cri to skip "Citation Matrix" module

FIG. 3. Start screen. File address and caption are inserted and Add pressed to activate HistCite software.

first step in constructing this map is to compile a bibliography from the ISI Web of Science ${ }^{\circledR}$ or other database based on a search by keywords, cited authors, cited papers or books, or by a source journal. In a typical search, you obtain a list of citing papers (Fig. 1). You click on Marked List (XX) and the export file is saved in ASCII format (Fig. 2). When the HistCite software is opened up, a screen appears

\begin{tabular}{|c|c|c|}
\hline \multicolumn{3}{|c|}{$\begin{array}{l}\text { Citations to Kessler's Bibliographic Coupling and papers with BC in title/abstract } \\
\text { Nodes: } 223 \\
\text { Sorted by year, journal, volume, page. }\end{array}$} \\
\hline Nodes / Authors & GCS & LCS \\
\hline $\begin{array}{l}\text { O } 11963 \text { AMERICAN DOCUMENTATION 14(1):10-\& } \\
\text { KESSLER MM } \\
\text { Bibliographic Coupling Between Scientific Papers }\end{array}$ & 128 & $\underline{134}$ \\
\hline $\begin{array}{l}12 \text { 1963 AMERICAN DOCUMENTATION 14(4):289-\& } \\
\text { GARFIELD E } \\
\text { Citation indexes in Sociological and Historical Research }\end{array}$ & 61 & $\underline{6}$ \\
\hline $\begin{array}{l}031963 \text { IEEE TRANSACTIONS ON INFORMATION THEORY 9(1):49- } \\
\text { K } \\
\text { KESSLER MM } \\
\text { An Experimental Study of Bibliographic Coupling Between } \\
\text { Technical Papers }\end{array}$ & 8 & 9 \\
\hline $\begin{array}{l}141963 \text { INFORMATION STORAGE AND RETRIEVAL 1(4): 169-187 } \\
\text { KESSLER MM } \\
\text { Bibliographic Coupling Extended in Time-10 Case Histories }\end{array}$ & 14 & 15 \\
\hline $\begin{array}{l}151964 \text { ASLIB PROCEEDINGS 16(2):48-63 } \\
{\left[\begin{array}{l}\text { Anon] } \\
\text { Aslib 37th Annual Conference - University of St Andrews, } \\
24 t h-26 \text { th September } 1963\end{array}\right.}\end{array}$ & & 0 \\
\hline $\begin{array}{l}161964 \text { ASLIB PROCEEDINGS 16(4):132-152 } \\
\text { LANCASTER FW } \\
\text { Mechanized Document Control - A Review of Some Recent } \\
\text { Research }\end{array}$ & 3 & 0 \\
\hline $\begin{array}{l}271964 \text { ASLIB PROCEEDINGS } 16(8) \cdot 246-251 \\
\text { KEEN EM } \\
\text { Citation indexes }\end{array}$ & 5 & $\underline{2}$ \\
\hline $\begin{array}{l}081964 \text { JOURNAL OF DOCUMENTATION 20(4):236-236 } \\
\text { MARTYN J } \\
\text { Bibliographic Coupling }\end{array}$ & 12 & 7 \\
\hline $\begin{array}{l}191964 \text { NACHRICHTEN FUR DOKUMENTATION 15(3):122-130 } \\
\text { MODEL F } \\
\text { Citation Index and Retrospective Cataloging - Examples of } \\
\text { Citation Documentation }\end{array}$ & 5 & 0 \\
\hline $\begin{array}{l}101964 \text { SCIENCE 144(361):649-\& } \\
\text { GARFIELD E } \\
\text { Science Citation Index-New Dimension in Indexing - Unique } \\
\text { Approach Underlies Versatile Bibliographic Systems for } \\
\text { Communicating + Evaluating Information }\end{array}$ & 92 & 19 \\
\hline $\begin{array}{l}311 \text { 1965 AMERICAN DOCUMENTATION 16(3):223-233 } \\
\text { KESSLER MM } \\
\text { Comparison of the Results of Bibliographic Coupling and } \\
\text { Analytic Subject indexing }\end{array}$ & 42 & 43 \\
\hline
\end{tabular}

FIG. 2. Marked records field options and save to file.
FIG. 4. Chronologic output file after HistCite ${ }^{\mathrm{TM}}$ processing. 


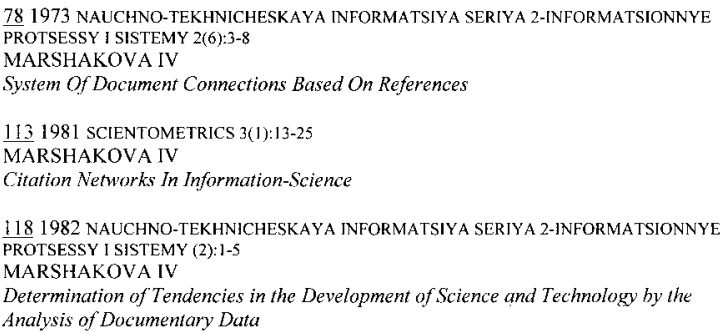

FIG. 5. Papers published by I.V. Marshakova including 1973 primordial paper on cocitation clustering.

that asks you to add the saved file address. You click the browse button and select the appropriate file address and then click add (see Fig. 3). You can also add a caption text for the network. The address for the saved file is used to activate the HistCite software. Once the program is activated, processing is completed in about one minute for a file of 500-1,000 source records. It is essential to reiterate that for each source record captured, its entire list of cited references must be included. Although records without cited references will be included in the final bibliography, they could not by definition provide backward links.

The Science Citation Index ${ }^{\circledR}\left(S C I^{\circledR}\right)$, Social Sciences $C i$ tation Index ${ }^{\circledR}\left(S_{S C I}\right)$, and Arts and Humanities Citation

\begin{tabular}{|c|c|}
\hline \multicolumn{2}{|c|}{$\begin{array}{l}\text { ISI Web of Science location: } \\
\text { Cited references outside of this network. } \\
\text { Total: } 6320 \text { (top } 100 \text { shown). }\end{array}$} \\
\hline LCS & Reference \\
\hline & PRICE DJD, 1965, SCIENCE, V149, P510 WOS \\
\hline & GARTIELD E, 1955, SCIENCE, V122, P108 WOS \\
\hline & GARFIELD E, 1979, CITATION IMDEXING WOS \\
\hline & GAREIELD E, 1964, USE CITATION DATA WR WOS \\
\hline & GRIREITH 3C, 1974, SCI STID, V4, 9339 WOS \\
\hline & GAREIELD E, 1972, SCIENCE, V178, P471 WOS \\
\hline & SAALTON G, 1983 , INTRO MODERN INFORMA WOS \\
\hline & MARGOLIS J, 1967, SCIENCE, V155, P1213 WOS \\
\hline & MORAVCSIK MJ, 1975, SOC STUD SCI, V5, P8E WOS \\
\hline & CRANE D, 1972, INVISIBIE COLLEGES WOS \\
\hline & SALTON G, 1963 , J ACM, V10, F440 WOS \\
\hline & SMALI HG, 1977, SOC STUD SCI, V7, P139 WOS \\
\hline & MRRIN F, 1976, EVALUATIVE BIBLIOMET WOS \\
\hline & WHITE HD, 1981, J AM SOC INFORM SCI, V32, P163 WOS \\
\hline & RUHH TS, 1970 , STRUCTURE SCI REVOLU WOS \\
\hline & WESTBROOK JH, 1960, SCIENCE, V132, P1229 WOS \\
\hline & PRIICHARD A, 1969, J DOC, V25, P348 WOS \\
\hline & KWOK KL, 1975, INFORMAEION PROCESSI, V11, P201 WOS \\
\hline & KAPLAN N 1965, AM DOC, V16, 1179 WOS \\
\hline & CHUBTN DE, 1975, SOC STUD SCI, V5, P423 WOS \\
\hline & LOTKA AJ, 1926 , J WASHENGTON ACADEMY, V16, P317 WOS \\
\hline & GARFIETD E, 1979 , CITAEION INDEXING IT WOS \\
\hline & UVANRIJSEERGEN CJ, 1979, INFORMATION RETRIEVA WOS \\
\hline & SMALI HG, 1978, SOC STUD SCI, VA, P327 WOS \\
\hline & NARIN F, 1972, J AM SOC INIORM SCI, V23, P323 WOS \\
\hline & GAREIEID E, 1980, CURRTNT CONTENT 0609, P5 WOS \\
\hline & PRICE. DJD, 1966, AM PSYCHOL, V21, P1011 WOS \\
\hline & GARFIEID E, 1970, NATURE, V227, P669 WOS \\
\hline & BUSE V, 1945, ATLANTIC WONTELY, V176, P101 WOS \\
\hline & PINSKI $G, 1976$, INFORMATION PROCESSI, V12, P297 WOS \\
\hline
\end{tabular}

FIG. 6. Outer references ranked by citation frequency.

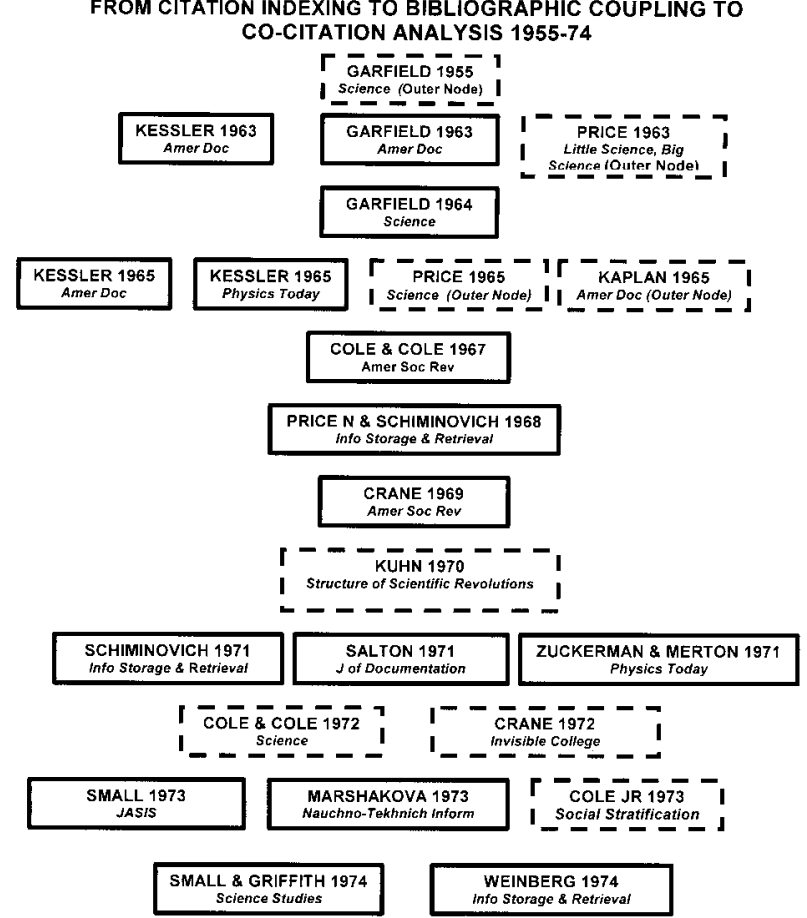

FIG. 7. Historigraph of bibliographic coupling from 1955 to 1974. Dotted lines indicate outer references.

Index ${ }^{\circledast}\left(A H \& C I^{\circledast}\right)$ on CD ROM, on the Web of Science, or on Dialog can be used to create the import file. Once completed, the program displays the output in the form of a chronological table arranged in order by year, journal, volume, and page. A typical display is shown in Figure 4. Each item is assigned a node serial number, and for each paper there is a Global Citation Score (GCS) as well as a Local Citation Score (LCS). By clicking on either GCS or LCS, the researcher is presented with a ranked sort of the collection starting with the most-cited paper at the top. The GCS is the number of times the paper is cited in the SCI. The LCS is the number of times the paper is cited in the collection.

Although there are exceptions, it has been well documented that the key works in most fields are well correlated with citation frequency. To construct the history of bibliographic coupling Garfield (Garfield, 2001a) began the WoS cited reference search with the primordial paper by Michael M. Kessler (Kessler, 1963). That paper can be regarded as a symbol for the topic of bibliographic coupling. Nevertheless, for whatever reasons, some authors either have forgotten the paper or do not think it necessary to cite Kessler's paper even though the titles of their papers include the term bibliographic coupling. So the search was augmented with a title-word search that added a few dozen papers. The final bibliography contains a few hundred source papers, each of which has cited an average of 20 or more references. Thus, a virtual minicitation index consisting of 4-5,000 cited references was created.

Many citation variations are due to lack of standardization in citation practice. To capture all relevant papers one may have to modify the WoS search profile accordingly. For 
Geneflow Papers - 1974 to August 2001

See the Historiograph of the 29 most cited papers in LCS by clicking here Nodes: 620

Sorted by year, journal, volume, page.

\begin{tabular}{|c|c|c|c|}
\hline des & Nodes / Authors & GCS & $\underline{\mathrm{LCS}}$ \\
\hline & $\begin{array}{l}11974 \text { GENETICS 78(3):961-965 } \\
\text { SPIETH PT } \\
\text { Gene Flow and Genetic Differentiation }\end{array}$ & 43 & $\underline{9}$ \\
\hline & $\begin{array}{l}21975 \text { AMERICAN NATURALIST 109(969):597-601 } \\
\text { SLATKIN M; MARUYAMA T } \\
\text { Influence of Gene Flow on Genetic Distance }\end{array}$ & 21 & $\underline{6}$ \\
\hline & $\begin{array}{l}31975 \text { AMERICAN NATURALIST 109(970):659-676 } \\
\text { MAY RM; ENDLER JA; MCMURTRIE RE } \\
\text { Gene Frequency Clines in Presence of Selection Opposed } \\
\text { by Gene Flow }\end{array}$ & 88 & 15 \\
\hline & $\begin{array}{l}41975 \text { AUK 92(3): } 493-510 \\
\text { COOKE F; MACINNES CD; PREVETT JP } \\
\text { Gene Flow Between Breeding Populations f Lesser Snow } \\
\text { Geese }\end{array}$ & 71 & $\underline{3}$ \\
\hline & $\begin{array}{l}51975 \text { GENETICS } 80(2): 349-361 \\
\text { MCKENZIE JA } \\
\text { Gene Flow and Selection in a Natural Population of } \\
\text { Drosophila- Melanogaster }\end{array}$ & 17 & 0 \\
\hline & $\begin{array}{l}\text { 6 } 1975 \text { GENETICS 81(4):787-802 } \\
\text { SLATKIN M } \\
\text { Gene Flow and Selection in a 2-Locus System }\end{array}$ & 52 & $\underline{3}$ \\
\hline & $\begin{array}{l}71975 \text { HEREDITY } 34 \text { (JUN): } 407-415 \\
\text { BRUSSARD PF; VAWTER AT } \\
\text { Population Structure, Gene Flow and Natural Selection in } \\
\text { Populations of Euphydryas-Phaeton }\end{array}$ & 9 & 0 \\
\hline & $\begin{array}{l}81975 \text { JOURNAL OF MOLECULAR EVOLUTION 5(3):177-185 } \\
\text { ADAMS RP } \\
\text { Gene Flow Versus Selection Pressure and Ancestral } \\
\text { Differentiation in Composition of Species - Analysis of } \\
\text { Populational Variation of Juniperus-Ashei Buch Using } \\
\text { Terpenoid Data }\end{array}$ & 21 & 0 \\
\hline & $\begin{array}{l}91976 \text { GENETICS 83(3):S64-S64 } \\
\text { RODELL CF } \\
\text { Some Demographic Considerations of Gene Flow }\end{array}$ & & \\
\hline & $\begin{array}{l}101976 \text { JOURNAL OF BIOSOCIAL SCIENCE 8(4):309-333 } \\
\text { DYER KF } \\
\text { Patterns of Gene Flow Between Negroes and Whites in } \\
\text { United-States }\end{array}$ & 4 & \\
\hline
\end{tabular}

FIG. 8. Chronologic table of papers on gene flow from 1974 to 2001.

example, some papers do not cite either the first or second initial of the author, in this case M.M. Kessler. So in conducting the WoS search, one should anticipate such variants and, if necessary, iterate the search so that as many relevant papers as possible are pulled into the collection. The existence of such variants may not be noted until the first iteration of HistCite is finished. HistCite also makes it possible to identify some variants by assembling them either in the "missing links" or "outer references" lists. Another variant may be found in changed names. Some authors add or drop initials to their by-lines, as was the case for Henry Small. Married names are also an occasional variant.

Examining these lists will identify candidate papers that have cited a relevant work but do not initially get pulled into the network. A large number of these variants involve cites to specific pages of individual papers or books. Therefore, to be included in the network, the first page of these cited works has to be added, so that they can be matched against the fully paginated record for the source article involved. Initially, during the first iteration of the program, many variations may be observed. Some prove to be redundant because several different pages of the same work may be cited in a single source. Once the pagination is corrected, the citing source is accounted for in the network.
Other variations occur in journal title abbreviations. A particularly egregious example involved citations to a Russian article by Irina Marshakova. Her primordial paper on cocitation analysis is node \#78, not shown in Figure 4. It is shown in Figure 5 as part of her author output. This paper was published in Nauchno-Tekhnicheskaya Informatsiya. The abbreviation for the Russian journal has been cited variously, as, for example, NTI, Nauch Tekh Inform, with or without the series number as shown in Figure 5. The full journal title includes a series number, because the journal was published in two sections. Most Western journals published in sections use alphabetic characters. For example, the well-known Physical Review is published in six sections: A, B, C, D, E, and F. After editing all the variant citations to Marshakova's paper, the citation count increased from 3 to 20. Fortunately, we cannot demonstrate all of these variations now because they have since been corrected in the WoS database.

Although the task of editing and correcting variations is important, it is secondary to the task of examining and editing the list of "outer references" (Fig. 6). These are cited references that do not match any items in the main bibliography. These are sorted by citation frequency. These outer references normally outnumber the nodal bibliography papers by a factor of ten or more because each source paper cites 20 or more works. Large numbers of variations turn up in the outer references. The variants in the file of outer

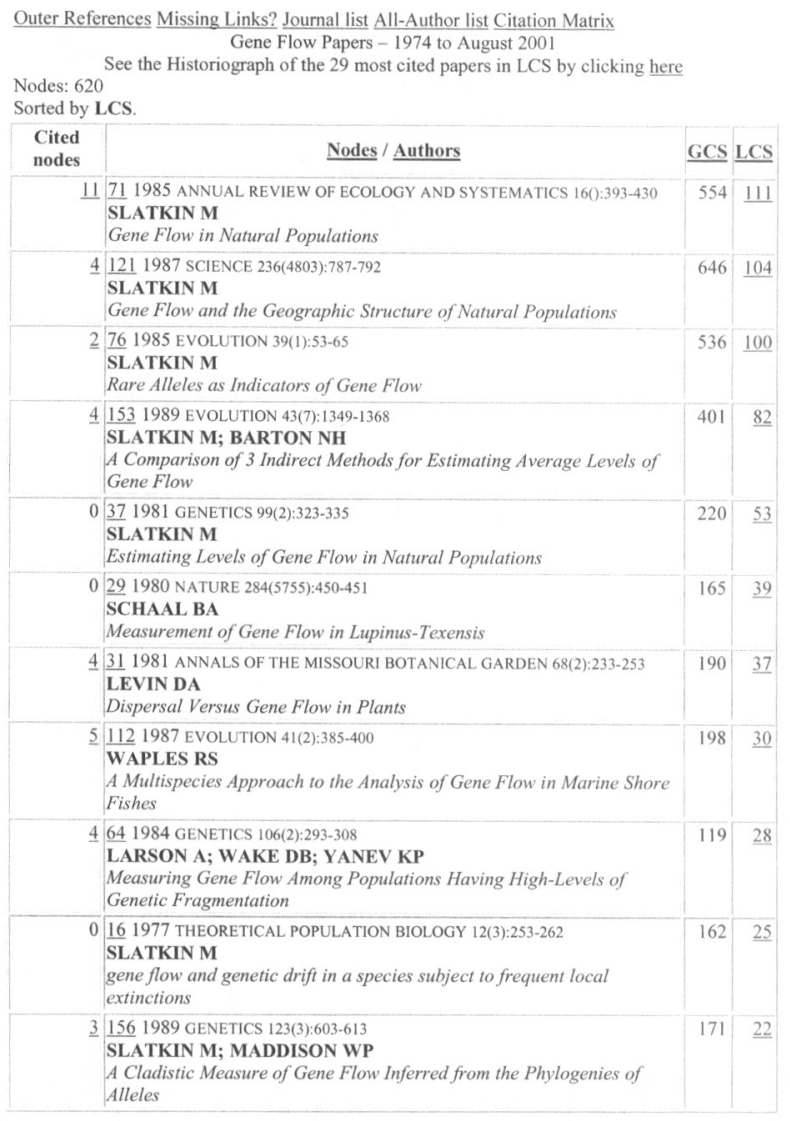

FIG. 9. Gene flow collection sorted by local citation score (LCS). 


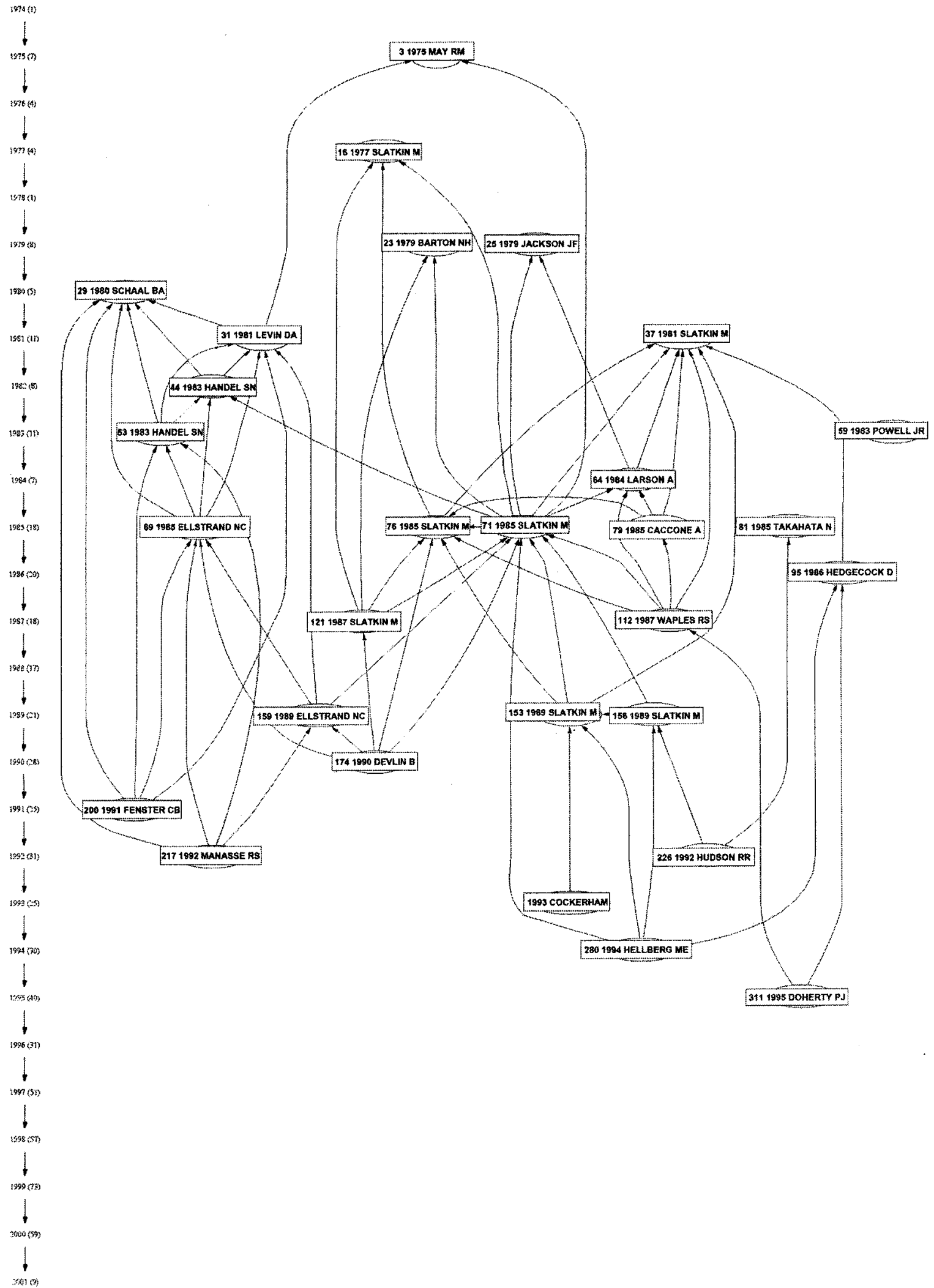

FIG. 10. Graphic presentation of gene flow collection.

references are best identified and edited by sorting them by cited author or by using the "Find" command of your browser to find all entries for one author at a time. However, of greater significance, the outer references collection provides a potential pool of core papers and books. By definition, these works were not retrieved in the original WoS 


\begin{tabular}{|c|c|}
\hline Author(s) & MAY RM; ENDLER JA; MCMURTRIE RE \\
\hline Title & $\begin{array}{l}\text { GENE FREQUENCY CLINES IN PRESENCE OF SELECTION } \\
\text { OPPOSED BY GENE FLOW }\end{array}$ \\
\hline Journal & AMERICAN NATURALIST 109(970):659-676 \\
\hline Year & 1975 \\
\hline Type & Article \\
\hline Address & PRINCETON UNIV,BIOL DEPT,PRINCETON,NJ 08540 \\
\hline Abstract & \\
\hline Wos cs & 88 \\
\hline LCS & 15 \\
\hline cites & 0 \\
\hline CR[17] & 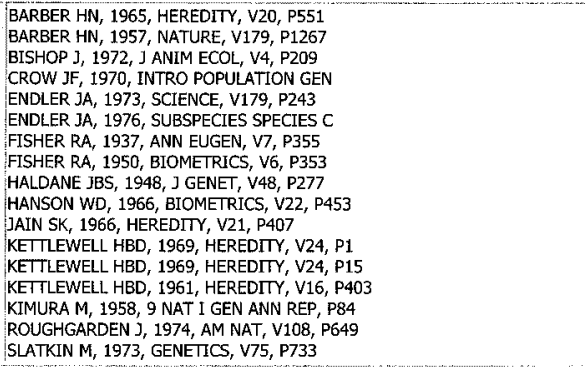 \\
\hline
\end{tabular}

FIG. 11. Full source entry for none \#3, paper by R.M. May, American Naturalist, 1975.

search because they did not cite the primordial work of Kessler. However, they were frequently cited by the papers that did cite Kessler. Indeed, many of these outer references are key works that contributed to the evolving history of the topic. Hence, works by Garfield and others published prior to 1963 will turn up as outer references. However, many papers published after 1963, which have been cocited with Kessler, also prove to be essential to the subject. Indeed, an important by-product of the algorithm is the ability to identify candidate papers for performing a cocitation mapping exercise.

The ultimate hand-drawn map of the topic of bibliographic coupling for 1955-1974 is shown in Figure 7. As can be seen, the map is arranged chronologically. From its citation frequency in this collection, it was determined that Garfield's 1955 paper in Science was an essential predecessor to the work on bibliographic coupling even though in his 1963 paper Kessler himself did not cite it. The Garfield paper appeared in the list of outer references (Fig. 6), as did the 1963 work by Derek de Solla Price, Little Science, Big Science. The book did not explicitly cite the Kessler paper. Upon further investigation, however, it was observed that Price acknowledged Kessler's technical reports in a footnote. By virtue of its inclusion in outer references it was realized that the Price work was essential to a more detailed history of this topic. Historiography involves making judgments and selections. But the basis for these selections must be a comprehensive display of candidate works, and the system also permits one to identify key linking or transition papers that may or may not be well cited.

Even a scholar with a photographic memory like Isaac Asimov can overlook some transitional key works that were involved in the development of a field (Garfield, Sher, \& Torpie, 1964).

In a similar fashion, the history of the topic of cocitation analysis was reconstructed (Garfield, 2001b). It was clearly

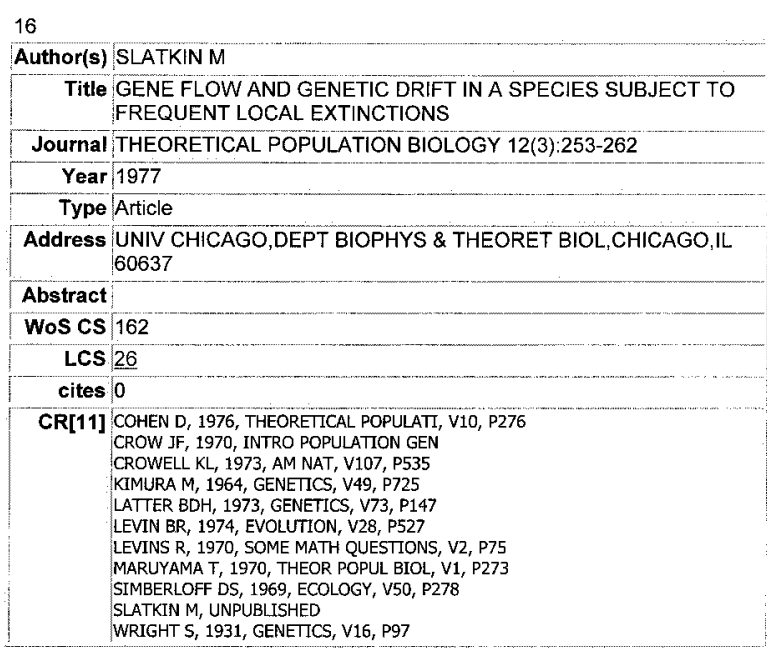

FIG. 12. Full source entry for M. Slatkin's 1977 paper. WoS CS is Global Citation Source.

shown that this topic is a logical extension of bibliographic coupling. However, the literature had grown from a few hundred papers to over 1,000. In the evaluation of the topic, the key role of later researchers like Howard White and Katherine McCain could be seen. Indeed, the process goes to the heart of understanding the paradigmatic shift from bibliographic coupling to cocitation to coword analysis.

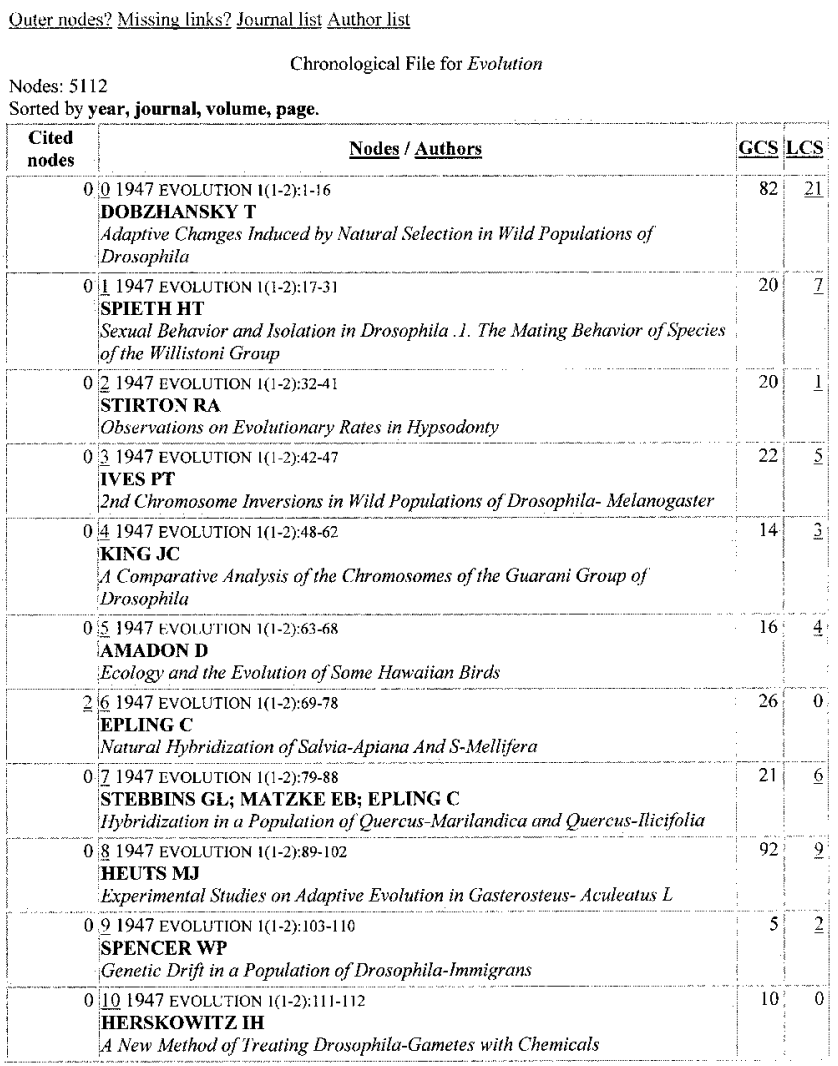

FIG. 13. Chronologic view of all papers published in Evolution, 1947 TO 1998 using an earlier version of HistCite software. 


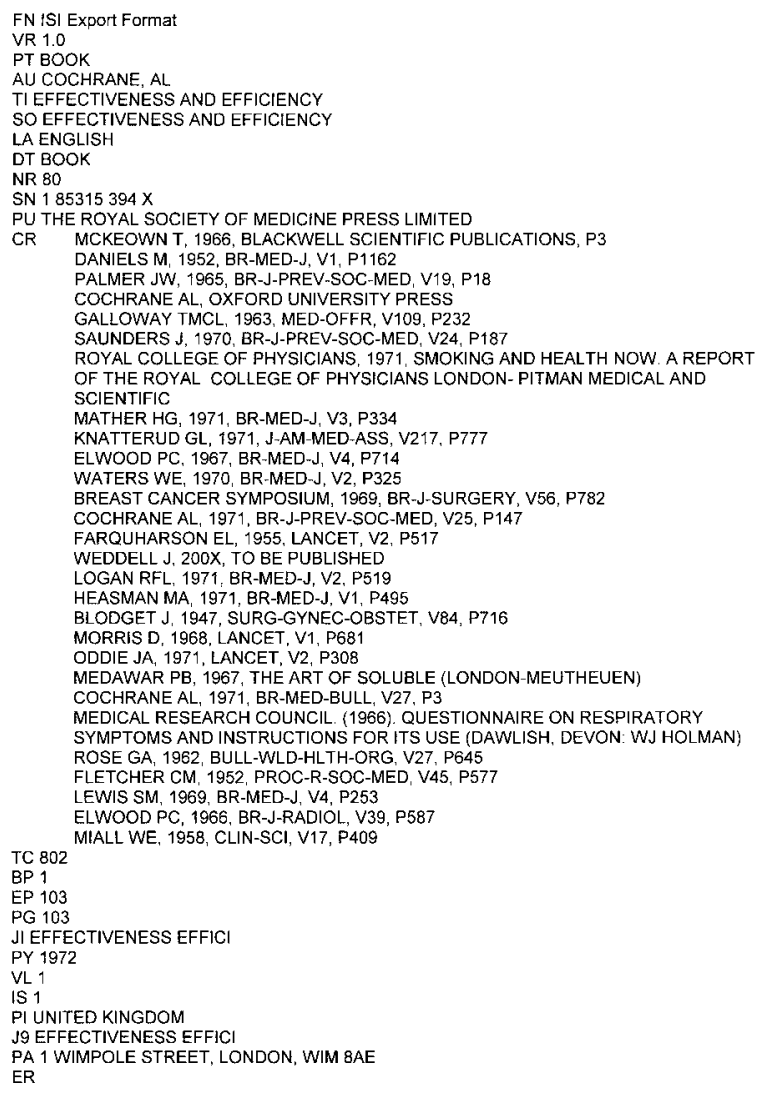

FIG. 14. Pseudosource record for Cochrane book, Effectiveness and Efficiency.

Let's turn now to an entirely different application of the Historiographer process to the topic of "gene flow." This is a subject of considerable interest to one of us (Pudovkin). Instead of a cited reference search, we conducted a general search in WoS using the simple term "gene flow" and limited the search to title words. Six hundred papers were published on this topic between 1974 and 2001 (Fig. 8). Of these, 29 papers were locally cited 10 or more times (Fig. 9), and were used to create a historiograph of the field. Thus, we are presented with a graphical description of the structure of this topic in Figure 10. Note that each rectangular node is hotlinked to the full source entry (Fig. 11). Node \#3 is Richard May's 1975 paper in the American Naturalist.

Gene flow is an important problem in population genetics. Gene flow maintains the unity of a species: the less the gene flow, the stronger the genetic differentiation among separate geographic populations. The intensity of gene flow is very difficult to measure directly. Many indirect estimation procedures have been suggested. In 1977 Mongomery Slatkin (now at UC Berkeley) published the first paper in a series of papers on the subject (16. Slatkin, 1977) (Fig. 12). Later he suggested using measures of allelic differences among populations to estimate the gene flow. These highly cited papers are cited both globally and locally (see nodes $37,71,76,121,153)$. The 1980 s were a time of great allozymic research activity, and allele frequency data were very easy to get. Later, in 1992, he and coauthors Hudson and Maddison (node 226) suggested the use of DNA-sequence data to estimate gene flow. This paper has not yet been cited very often because practical implementation of the approach is not easy.

The gene flow example is a work in progress because we must now correct errors or variations in cited references and feed the corrected versions into the main collection. We must also add outer references to the main collection that are perceived as important for inclusion in the historiograph. And the collection can be further increased by including all papers that cite the early work of Slatkin or others.

In constructing the complete database for any topic, one must contemplate performing an iterative process. One must decide whether or not any of the retrieved papers in a search should be used to further expand the file. This is sometimes called chain indexing. A cited reference search can be performed on any of the early citing papers to find additional papers that should be added to the original marked list. There is a wide variation in the degree of relatedness of citing papers. Some may cite many papers in the network. Others may cite only the one used for the cited reference search. Those that are heavily coupled bibliographically to the existing file should be included in the ultimate historio-

\begin{tabular}{|c|c|c|}
\hline \multicolumn{3}{|l|}{$\begin{array}{l}\quad 1971-2001 \text { Citations to A.L.Cochrane's 'Effectiveness and Efficiency' } \\
\text { Nodes: } 835 \\
\text { Sorted by year, journal, volume, page. }\end{array}$} \\
\hline Nodes / Authors & $\underline{G C S}$ & $\underline{L C S}$ \\
\hline $\begin{array}{l}0 \underline{0} 1972 \text { EFFECTIVENESS AND EFFICIENCY 1(1):1-103 } \\
\text { COCHRANE AL } \\
\text { Effectiveness And Efficiency }\end{array}$ & 802 & 834 \\
\hline $\begin{array}{l}1 \frac{1}{1} 1972 \text { INTERNATIONAL JOURNAL OF EPIDEMIOLOGY 1(4);315- } \\
318 \\
\text { HETZEL BS } \\
\text { implications of Health indicators }\end{array}$ & 6 & 0 \\
\hline $\begin{array}{l}1 \frac{2}{368} 1972 \text { INTERNATIONAL JOURNAL OF EPIDEMIOLOGY 1(4):361- } \\
\text { ROSSER RM; WATTS VC } \\
\text { Measurement of Hospital Output }\end{array}$ & 88 & 0 \\
\hline $\begin{array}{l}131972 \text { INTERNATIONAL JOURNAL OF HEALTH SERVICES } \\
2(4): 525-529 \\
\text { WHITE KL } \\
\text { Teaching Epidemiologic Concepts As Scientific Basis for } \\
\text { Understanding Problems of Organizing and Evaluating } \\
\text { Health Services }\end{array}$ & 1 & 0 \\
\hline $\begin{array}{l}141972 \text { JOURNAL OF BIOSOCIAL SCIENCE 4(4):490-494 } \\
\text { RICHARDS MP } \\
\text { introduction to Study of Man - Young, } J Z\end{array}$ & & 0 \\
\hline $\begin{array}{l}151972 \text { MILBANK MEMORIAL FUND QUARTERLY 50(4):17-40 } \\
\text { WHITE KL } \\
\text { Health Care Arrangements in United-States - AD } 1972\end{array}$ & 6 & 1 \\
\hline $\begin{array}{l}16 \text { } 1972 \text { NEW ENGLAND JOURNAL OF MEDICINE 287(2):100-\& } \\
\text { INGELFIN.FJ } \\
\text { Randomized Clinical Trial }\end{array}$ & 34 & 0 \\
\hline $\begin{array}{l}1.7972 \text { NEW ENGLAND JOURNAL OF MEDICINE 287(4):186-8 } \\
\text { LISTER J } \\
\text { By London Post-Effectiveness and Efficiency in Health Care }\end{array}$ & & 0 \\
\hline $\begin{array}{l}1 \frac{8}{8} 1972 \text { NEW ENGLAND JOURNAL OF MEDICINE 287(22):1125-\& } \\
\text { SANAZARO PJ; MAGLOTT DB; ROBERTS JS; } \\
\text { GOLDSTEI.RL; MCALLIST.JW } \\
\text { Research and Development in Quality Assurance - } \\
\text { Experimental Medical Care Review Organization Program }\end{array}$ & 39 & $\underline{3}$ \\
\hline $\begin{array}{l}191972 \text { NEW ENGLAND JOURNAL OF MEDICINE 287(24):1223-\& } \\
\text { WHITE KL; GAUS CR; MURNAGHA.JH } \\
\text { Technology And Health Care }\end{array}$ & 11 & $\underline{2}$ \\
\hline $\begin{array}{l}1 \text { 10 } 1972 \text { SCANDINAVIAN JOURNAL OF CLINICAL \& LABORATORY } \\
\text { INVETIGATION 29():36-\& } \\
\text { WOOD PHN } \\
\text { Connective Tissue Diseases and Community }\end{array}$ & & \\
\hline
\end{tabular}

FIG. 15. Chronologic historiographic display of citations to Cochrane's book, Effectiveness and Efficiency. 


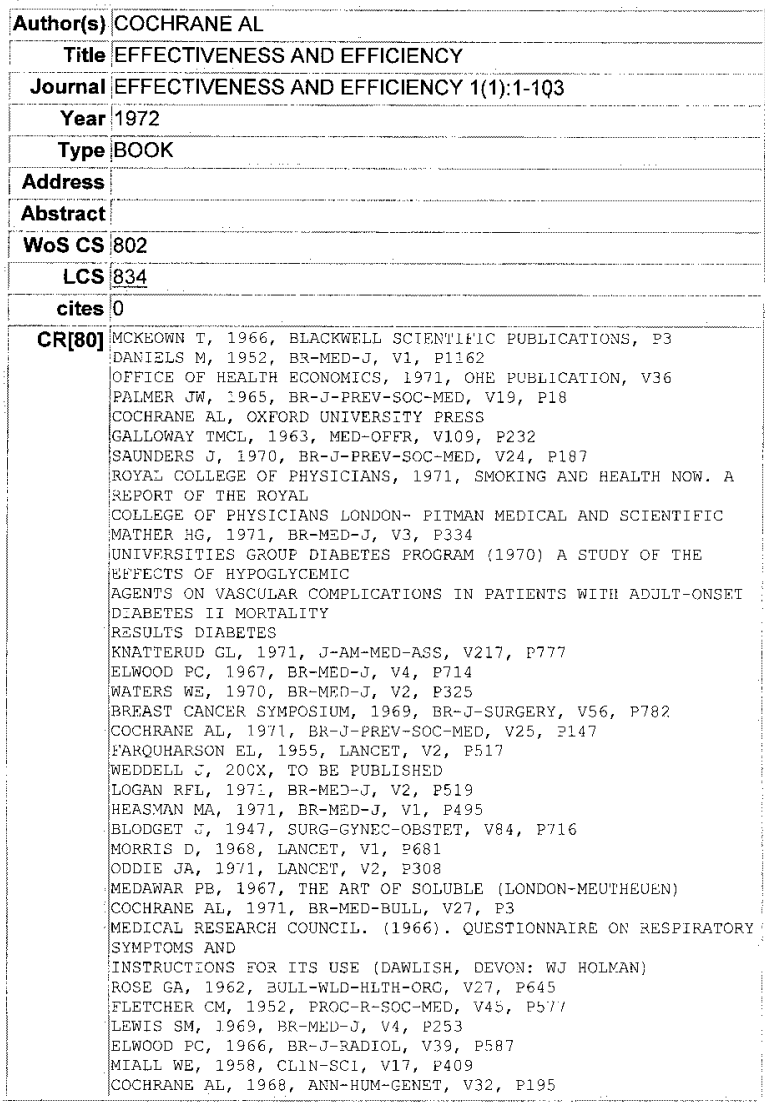

FIG. 16. Full source entry for node \#0, Cochrane's book Effectiveness and Efficiency

graph. Those that are only tangentially connected need not be included. A paper with 100 cited references may have cited only one paper in the nodal network. All the other 99 will go into the list of outer references. If none of the other papers in the collection have cited any of these papers, then they will all turn up at the bottom of the outer reference list when sorted by citation frequency. You can establish a cutoff threshold for selecting only those items cited above the threshold. Thus, the only limitation on expanding search results by chain citation indexing, or by expanding the vocabulary, is the number of items that must be processed by the program. Collections up to 5,000 source items have been easily accommodated, such as the entire file of papers published in the journal Evolution from 1947 to 1998 (http:// garfield.library.upenn.edu/histomp/evol45-98/) (Fig.13).

In the early development of a topic, using unlimited or unselective chain indexing is not dangerous. But when one encounters citing papers, which are in turn highly cited, then a decision must be made as to whether or not to proceed with chaining. Thus, if the classic Lowry method for protein determination (Lowry, Rosebrough, Farr, \& Randall, 1951) or some other method paper were encountered, we would have to decide whether to eliminate it from the collection. One way to temper a chain search is to look for cocitation between the highly cited paper and at least one or more of the papers in the core bibliography. What is the probability that a nonrelevant highly cited paper will have cited two or more papers on your topic? For example, it is not likely that the recent hot papers by Lander and Venter (Lander et al., 2001; Venter et al., 2001) on sequencing the human genome will have cited two or more papers on bibliographic coupling. It is highly likely that papers like the Lowry method will turn up in the outer references. But that will not cause a cascade of additional citing papers unless it is brought into the main bibliography, as would be the case in a history of protein development.

We have perhaps unduly stressed the potential errors and variations in cited references. From our experience to date the very first output of a topical search will identify the most significant papers on that topic. HistCite enables you to provide a more precise accounting of the citation frequencies involved. However, as was shown in the example of Marshakova, some significant works may be turned up by standardizing the variations in journal abbreviations and pagination.

Inevitably, one needs to add source documents to the main bibliography that have not been processed as sources in the WoS. To do this, one must manually create a source document. Consider the source record we created for the 1972 book "Effectiveness and Efficiency" by Archie Cochrane (Fig. 14). This book was cited in over 800 papers.

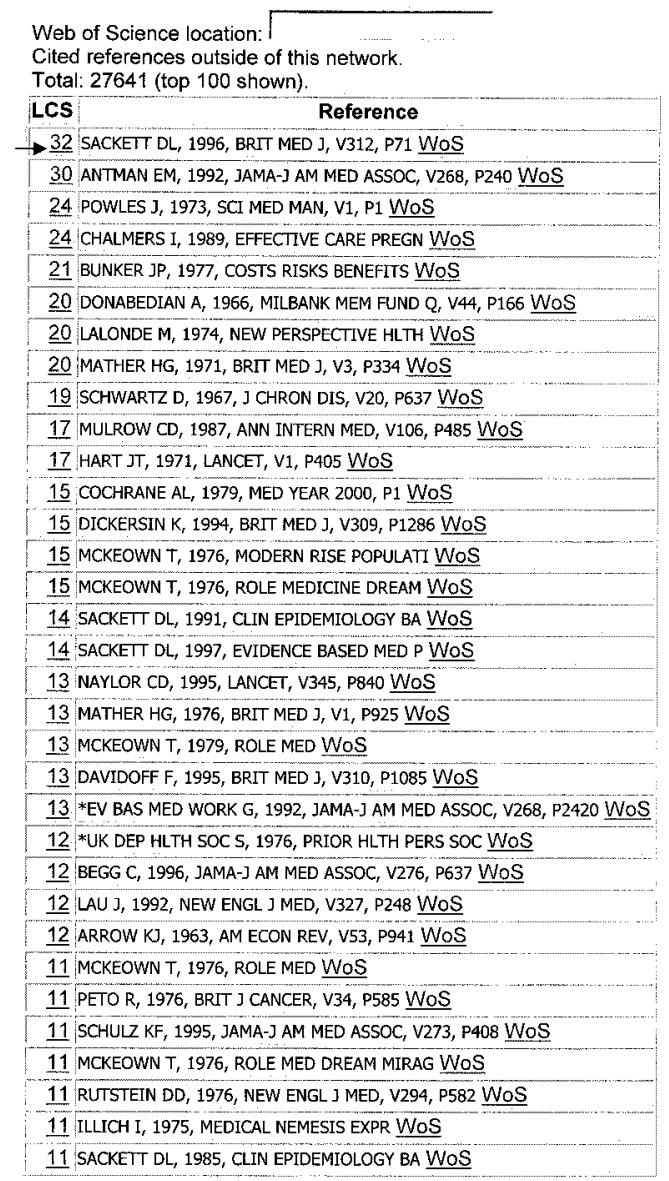

FIG. 17. Outer references for historiographic file on Cochrane's book. 


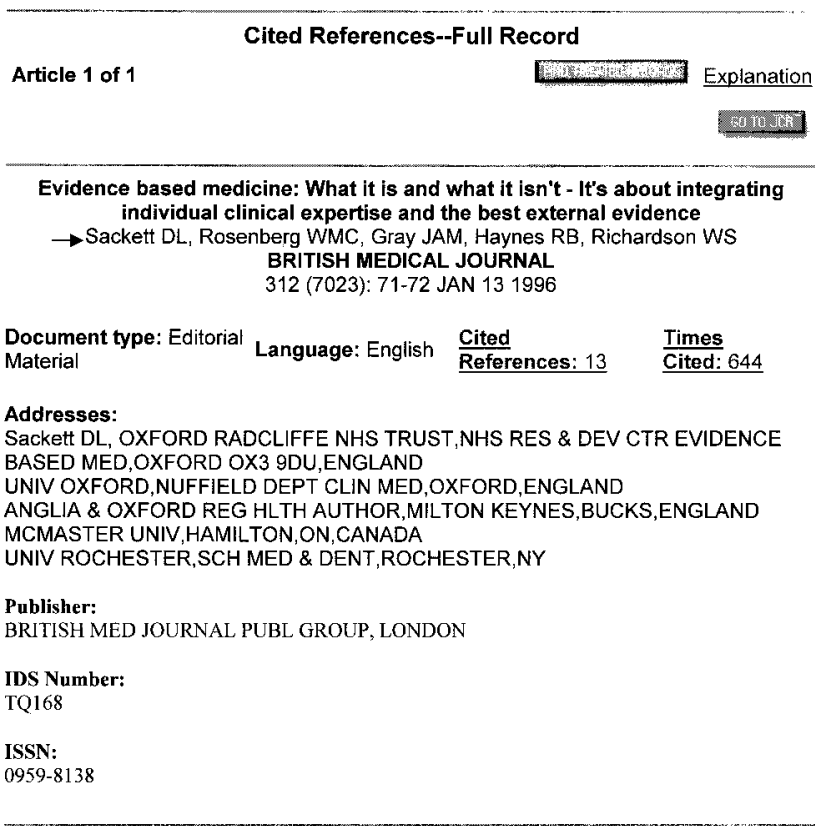

Article 1 of 1

Copyright $\odot 2002$ Acceptable Use Policy

02 Institute for Scientific Information

FIG. 18. WoS source record for D.L. Sackett's supercited 1996 paper on evidence-based medicine.

Following the WoS source style, we created a pseudojournal entry for the book itself. Eighty references are cited in the book. Each of the 80 cited references in the book is tagged CR. Each comma-delimited CR line contains author, year, journal or book, volume and page. Every volume and page must be preceded by $\mathrm{V}$ and $\mathrm{P}$.

The first part of the HistCite collection of papers that cite Cochrane's classic on evidence-based medicine is shown in Figure 15. Note that the GCS is lower than the LCS. This is because we edited 32 citing records that had cited a variation in pagination or whatever. GCS is the original WoS score. The source record for Node \#0 is shown in Figure 16, and the list of outer references is shown in Figure 17. Anyone familiar with this field will not be surprised that the classic work of Dave Sackett turns up. Its WoS entry is shown in Figure 18.

When the HistCite collection is sorted by Local Citation Score, the 1992 work of Iain Chalmers comes to the top (Fig. 19). The broad scope of this field is demonstrated when we sort by GCS (Fig. 20) and see the highly cited work of Wennberg and others.

At the suggestion of Chaomei Chen, it was decided to test the utility of HistCite on the topic of "information visualization." We approached his request from the perspective of a reference librarian who is asked to find the key works on this topic. Creating a bibliographic file based on key words rather than cited authors or papers can be problematic considering the inherent ambiguity in natural language. The specific term "information visualization" is actually of recent vintage. A search of the entire 56 year Web of Science using "inform* visuali*" produces only 147 hits. When the search is limited to the title word field, only 50 papers were found. The oldest paper was published in 1993 (Fig. 21). However, the phrase "visualization of information" was used as early as 1977 by two Russian authors (Fig. 22). Indeed, expanding the search query to "inform* same visuali*," produces another 1000 papers published from 1985 to the present. Nevertheless, we have used the smaller sample of 147 papers to create a sample HistCite file (Fig. 23) based on the two variant spellings for the phrase information visualization or information visualisation. The first three entries in Figure 23 were retrieved in a search of the pre-1980 literature, which was not limited to title words. Papers in gray indicate that they neither cite nor are they cited by any other papers in the collection.

Performing a keyword search is counter to our preference for searching by cited articles or authors. Nevertheless, the natural language search has indeed been successful. By sorting on LCS we find node \#4 is the most-cited paper in the bibliography. It was written by Robertson, Card, and Mackinlay at Xerox (Fig. 24). So

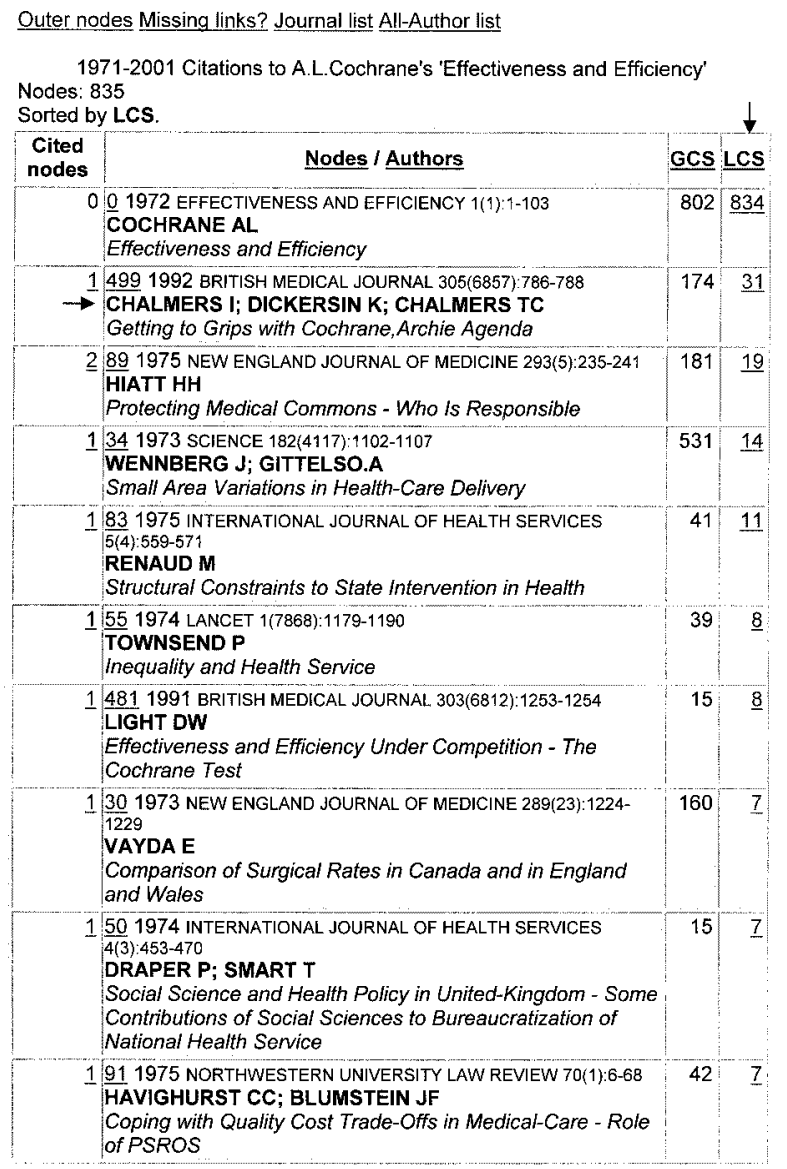

FIG. 19. Cochrane file sorted by local citation source (LCS). Chalmers 1992 paper follows Cochrane book. 
Uuter nodes Missing IInks? Journal list All-Author list

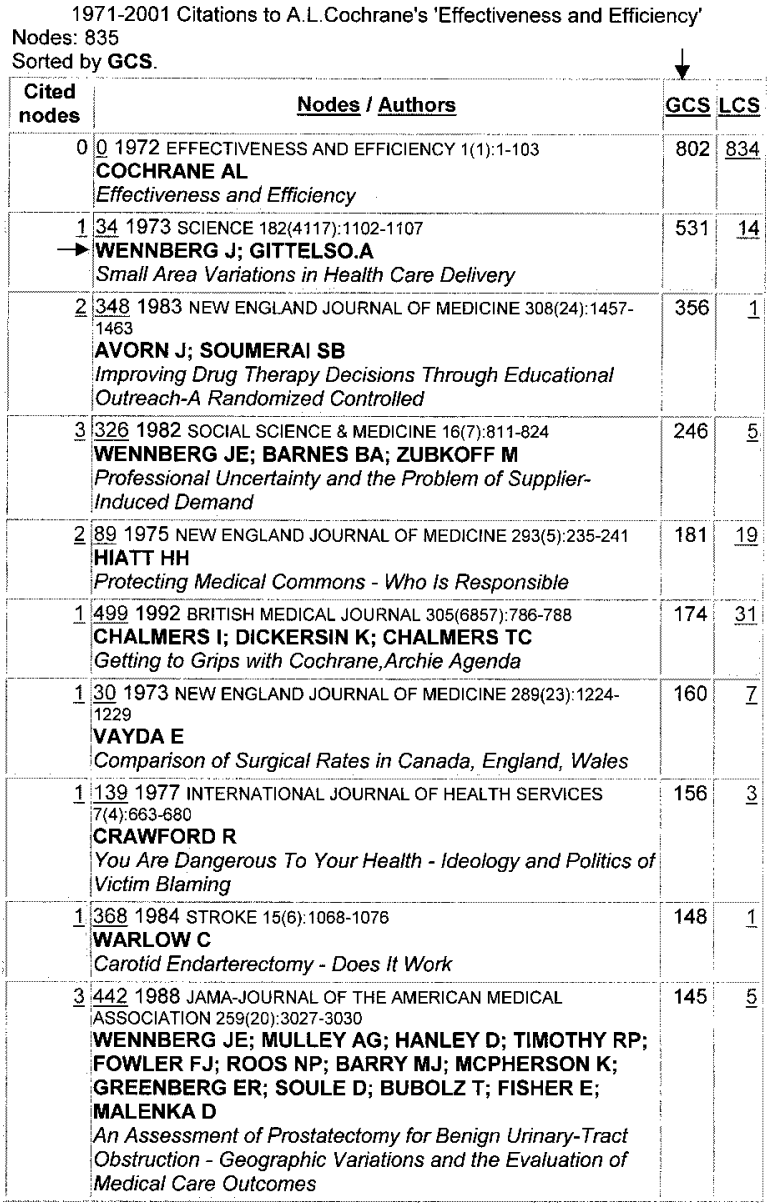

FIG. 20. Sort by global citation score (GCS) places Wennberg 1973 paper second.

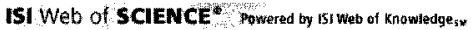

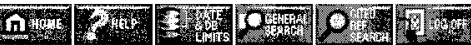

General Search Results--Summary

Title=inform ${ }^{*}$ visuali*: DocType=All document types; Language=All languages; Databases=SCI-EXPANDED, SSCI, A\&HCl; Timespan=All Years; (sorted by latest date)

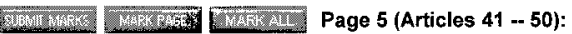$$
\text { V: }[\underline{1}|\underline{2}| \underline{3}|\underline{4}| 5]
$$

Use the checkboxes to add individual articles to the Marked List. Be sure to click SUBMIT MARKS button before leaving page.

Г. BAKER MP, BUSHELL C

AFTER THE STORM - CONSIDERATIONS FOR INFORMATION

AFTER THE STOR

IEEE COMPUT GRAPH 15 (3): 12-15 MAY 1995

- ROBERTSON GG, CARD SK, MACKINLAY JD INFORMATION VISUALIZATION USING 3D INTERACTIVE ANIMATION

$\longrightarrow$ COMMUN ACM $36(4) ; 57-71$ APR 1993

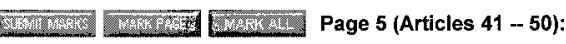

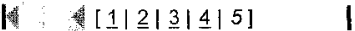

50 of 31000834 documents matched the query.

Acceptable Use Policy
Copyright $\odot 2002$ Institute for Scientific Information

FIG. 21. WoS search on information visualization-oldest paper.

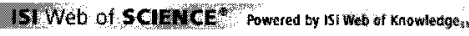

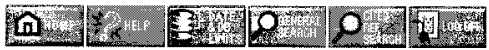

\section{General Search Results--Summary}

Topic=information and visuali*; DocType=All document types; Language=All languages Databases=SCl-EXPANDED, SSCI, A\&HCl; Timespan $=1960,1961,1962,1963,1964$, 1965, 1966, 1967, 1968, 1969, 1970, 1971, 1972, 1973, 1974, 1975, 1976, 1977; (sorted by latest date)

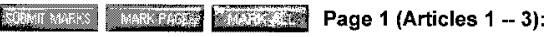

I [1] |

Use the checkboxes to add individual anticles to the Marked List. Be sure to click SUBMIT MARKS button before leaving page.

$\Gamma$ MERZLIAKOV NS, IAROSLAVSKII LP

$\longrightarrow$ VISUALIZATION OF INFORMATION USING SYNTHESIZED HOLOGRAMS DOKL AKAD NAUK SSSR+ 237 (2): 318-321 1977

$\Gamma$ EDWARDSON M, GROOMS D, PRINGLE P VISUALIZATION AND TV NEWS INFORMATION GAIN J BROADCASTING 20 (3): 373-380 1976

$\Gamma$ MACKAYRS

X-RAY VISUALIZATION AND ANALYSIS USING SPECTRAL INFORMATION IRE T MED ELECTRON 7 (2): 77-79 1960

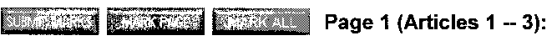

[1] I

3 of 6654992 documents matched the query. Acceptable Use Policy Copyright $\odot 2002$ Institute for Scientific information

FIG. 22. WoS search on information and visual*, 1960-1977. Outer References Missing Links? Journal list All-Author list Citation Matrix

Nodes: 147 Inform* Visuali* papers from 1992 to April 2002

Sorted by year, journal, volume, page

\begin{tabular}{|c|c|c|c|}
\hline $\begin{array}{l}\text { ted } \\
\text { des }\end{array}$ & Nodes / Authors & $\mathbf{s}$ & $\mathrm{CS}$ \\
\hline & $\begin{array}{l}1992 \text { CA NOIAN JOURNAL OF INFORMATION SCIENCE-REVUE: } \\
\text { CANADIEME DES SCIENCES DE LINFORMATION } 17(2): 4148 \\
\text { GRANDE S; ROBINSON D } \\
\text { Mutimedia and LiteracY }\end{array}$ & & \\
\hline & $\begin{array}{l}\text { 21 } 1993 \text { ACM TRANSACTIONS ON INFORMATION SYSTEMS } \\
\text { 11(3):266-286 } \\
\text { KOIKE } \mathrm{H} \\
\text { The Role of Another Spatial Dimension in Software } \\
\text { Visualization }\end{array}$ & 8 & 2 \\
\hline & 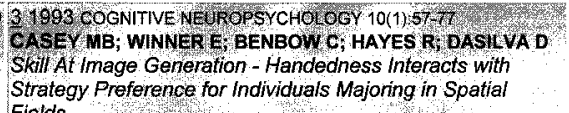 & 5 & \\
\hline & Fields & & \\
\hline & $\begin{array}{l}41993 \text { COMMUNICATIONS OF THE ACM } 36(4): 57-71 \\
\text { ROBERTSON GG; CARD SK; MACKINLAY JD } \\
\text { information Visualization Using 3d interactive Animation }\end{array}$ & 81 & 17 \\
\hline & 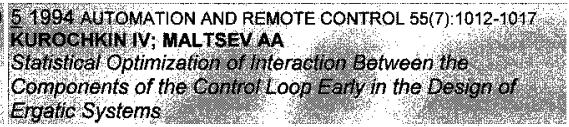 & & 淋 \\
\hline & 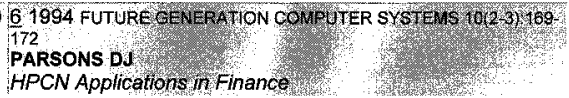 & & \\
\hline & $\begin{array}{l}\text { 7. } 1994 \text { INFORMAEON PROCESSING } 94, \text { VOL } / 1373513358 \\
\text { SCHUETT D, JACOBY K; BOCIONEK S } \\
\text { Information Engineering and Wnovation }\end{array}$ & & 0 \\
\hline & $\begin{array}{l}\text { 8 } 1995 \text { ACM TRANSACTIONS ON INFORMATION SYSTEMS } \\
\text { KOIK) } 305-323 \\
\text { Fractal Views - A Fracta Based Method for Controlling } \\
\text { information Display }\end{array}$ & & 0 \\
\hline & $\begin{array}{l}91996 \text { BRITISH TELECONMUNICATIONS ENGINEFRING } 14017 \\
\text { WALKER G } \\
\text { Challenges in infomation Visualization }\end{array}$ & 1 & \\
\hline & $\begin{array}{l}10 \text { 1995 COMPUTER GRAPHICS FORUM 14(3):C349-C360 } \\
\text { BENFORD S; SNOWDON D; GREENHALGH C; INGRAM R; } \\
\text { KNOX I; BROWN C } \\
\text { Vr-Vibe - A Virtual Environment for Cooperative Information } \\
\text { Retrieval }\end{array}$ & 4 & 1 \\
\hline
\end{tabular}

FIG. 23. Chronologic file of papers on inform* Visuali, 1992-2002. 
Uuter Reterences Missing Links? Journal IIst All-Author Iist Litation Matrix

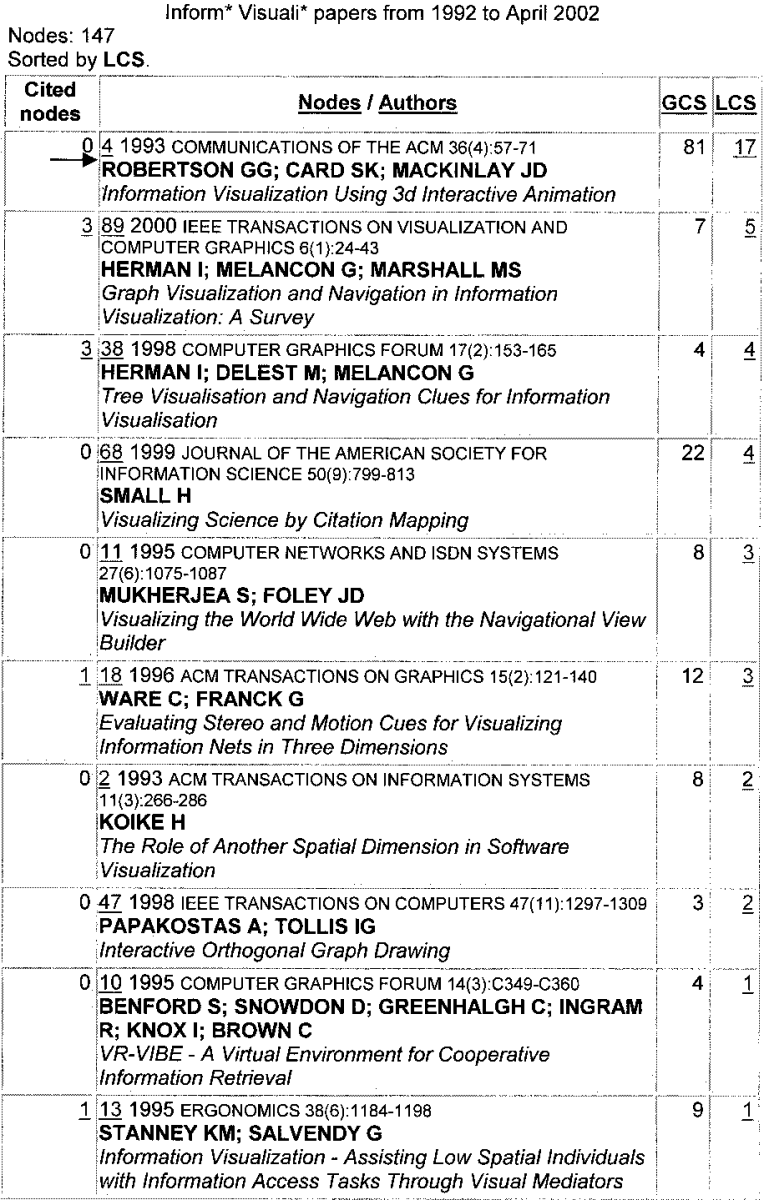

FIG. 24. Sort by local citation source (LSC) for papers on inform* Visuali*.

\begin{tabular}{|c|c|}
\hline Author(s) & ROBERTSON GG; CARD SK; MACKINLAY JD \\
\hline Title & $\begin{array}{l}\text { INFORMATION VISUALIZATION USING 3D INTERACTIVE } \\
\text { ANIMATION }\end{array}$ \\
\hline Journal & COMMUNICATIONS OF THE ACM 36(4):57-71 \\
\hline Year & 1993 \\
\hline Type: & \\
\hline Address & $\begin{array}{l}\text { XEROX CORP, PALO ALTO RES CTR, } 3333 \text { COYOTE HILL RD, } \\
\text { PALO ALTO, CA } 94304 \text { USA }\end{array}$ \\
\hline Abstract & \\
\hline Wos CS & 81 \\
\hline LCS & 17 \\
\hline cites $\mathrm{C}$ & 0 \\
\hline $\mathbf{C R}[25]$ & 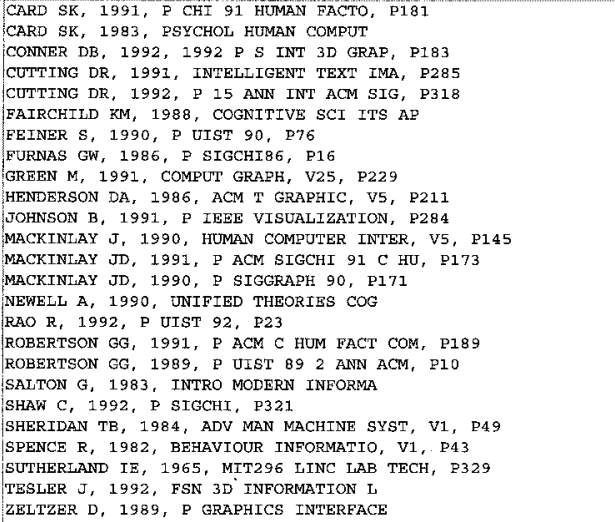 \\
\hline
\end{tabular}

FIG. 25. Full source entry for Robertson et al. gives hint of earlier work.
Outer References Missing Links? Journal list All-Author list Citation Matrix

\begin{tabular}{|c|c|c|c|}
\hline \multicolumn{4}{|c|}{ Inform* Visuali* papers from 1992 to April 2002} \\
\hline $\begin{array}{c}\text { Cited } \\
\text { nodes }\end{array}$ & Nodes / Authors & \multicolumn{2}{|c|}{ GCS LCS } \\
\hline & $\begin{array}{l}41993 \text { COMMUNICATIONS OF THE ACM 36(4):57-71 } \\
\text { ROBERTSON GG; CARD SK; MACKINLAY JD } \\
\text { information Visualization Using 3d Interactive Animation }\end{array}$ & 81 & 17 \\
\hline & $\begin{array}{l}\text { 68 } 1999 \text { JOURNAL OF THE AMERICAN SOCIETY FOR } \\
\text { INFORMATION SCIENCE 50(9):799-813 } \\
\text { SMALL H } \\
\text { Visualizing Science by Citation Mapping }\end{array}$ & 22 & $\underline{4}$ \\
\hline & 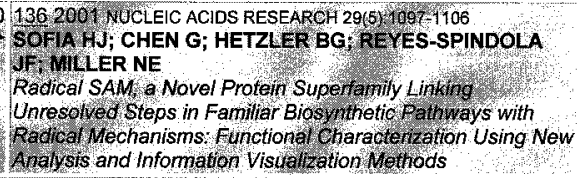 & 16 & \\
\hline & $\begin{array}{l}181996 \text { ACM TRANSACTIONS ON GRAPHICS 15(2):121-140 } \\
\text { WARE C; FRANCK G } \\
\text { Evaluating Stereo and Motion Cues for Visualizing } \\
\text { Information Nets in Three Dimensions }\end{array}$ & 12 & 3 \\
\hline & $\begin{array}{l}131995 \text { ERGONOMICS 38(6): } 1184-1198 \\
\text { STANNEY KM; SALVENDY G } \\
\text { Information Visualization - Assisting Low Spatial Individuals } \\
\text { with information Access Tasks Through Visual Mediators }\end{array}$ & 9 & 1 \\
\hline & $\begin{array}{l}\text { 2 1993 ACM TRANSACTIONS ON INFORMATION SYSTEMS } \\
11(3): 266-286 \\
\text { KOIKE H } \\
\text { The Role of Another Spatial Dimension in Soffware } \\
\text { Visualization }\end{array}$ & 8 & $\underline{2}$ \\
\hline & $\begin{array}{l}111995 \text { COMPUTER NETWORKS AND ISDN SYSTEMS 27(6):1075- } \\
1087 \\
\text { MUKHERJEA S; FOLEY JD } \\
\text { Visualizing the World Wide Web with the Navigational View } \\
\text { Builder }\end{array}$ & 8) & 3. \\
\hline & $\begin{array}{l}191996 \text { ARTIFICIAL INTELLIGENCE REVIEW 10(5-6):477-504 } \\
\text { ZAVREL J } \\
\text { Neural Navigation Interfaces for Information Retrieval: Are } \\
\text { They More Than an Appealing idea? }\end{array}$ & 8 & 1 \\
\hline & $\begin{array}{l}281997 \text { COMEUTERS \& GEOSCIENCES } 23(4): 447-456 \\
\text { CARTWRIGHT W } \\
\text { NeW Media Application to the Production of Map Products }\end{array}$ & 7 & 0 \\
\hline & $\begin{array}{l}892000 \text { IEEE TRANSACTIONS ON VISUALIZATION AND } \\
\text { COMPUTER GRAPHICS } 6(1): 24-43 \\
\text { HERMAN I; MELANCON G; MARSHALL MS } \\
\text { Graph Visualization and Navigation in Information } \\
\text { Visualization: A Survey }\end{array}$ & 7 & 5. \\
\hline
\end{tabular}

FIG. 26. Sort by global citation source (GCS) of inform* visual*.

far this is the earliest paper encountered that uses the term "information visualization" as a title word. Examination of the list of references cited in this paper (Fig. 25) gives a hint of earlier work.

However, when the file is sorted by Global Citation Score, the second most cited paper, Node \#68, is Henry Small's 1999 paper on "Visualizing Science by Citation Mapping," published in JASIST (Fig. 26).

Also in Figure 26, the third paper, by Sofia, was cited by 16 papers globally. Published in Nucleic Acids Research in 2001, the paper concerns a novel protein superfamily and uses information visualization methods. Thus, we are thrust into the large biotechnology literature which is outside "information visualization" per se. Note that it is not linked to any of the other papers in the sample network!

Figure 27 shows the list of outer references and identifies the two earlier 1990 conference papers by GG Robertson and Mackinlay that they cited earlier.

Following these in Figure 27 is the "granddaddy" of the overall field of visualization, Edward R. Tufte's 1983 book, The Visual Display of Quantitative Information. This classic 
has been cited hundreds of times. So has his 1990 book Envisioning Information. Note also that the 1983 book has been cited as E. Tufte, so this variation should be edited to show its true rank as the most-cited outer reference.

A 1992 paper by Ben Shneidermann also appears in Figure 27. Although it has only been cited eight times, most of those occur within the network. The title, "Tree Visualizations with Tree Maps," illustrates all too well the difficulty in retrieving all relevant work easily by natural language and explains why it was not found in the original search by title.

Thus, in a 15-minute exercise, including the time to do the $W o S$ search, it was possible to identify the key works on this topic. When we extended this search to a larger file of over 800 papers on information visualization, it is significant that the most-cited works were essentially the same.

Of course, a citation-conscious searcher might build up the bibliography on this topic by beginning with one or more known key papers or authors such as Robertson or Tufte. By examining successive historiographic tables, we believe all roads would essentially lead to the identification of the key works in the field.

An interesting by-product of this search is worth mentioning. When the key source paper by Robertson et al. was originally processed by ISI, the first page was listed as page

\begin{tabular}{|c|c|}
\hline \multicolumn{2}{|c|}{$\begin{array}{l}\text { ISI Web of Science location: } \\
\text { Cited references outside of this network. } \\
\text { Total: } 3225 \text { (top } 100 \text { shown). }\end{array}$} \\
\hline LCS & Reference \\
\hline & ROBERTSON GG, 1991, P ACM C HUM FACT COM, P189 WOS \\
\hline & SARKAR M, 1994, COMMUN ACM, V37, P73 WOS \\
\hline 12 & MACKINLAY JD, 1991, P ACM SIGCHI 91 C HU, P173 WoS \\
\hline$\rightarrow 11$ & TUFTE ER, 1983, VISUAL DISPLAY QUANT WOS \\
\hline 10. & JOHNSON B, 1991, P IEEE VISUALIZATION, P284 WOS \\
\hline & CARD SK, 1999, READINGS INFORMATION WOS \\
\hline 101 & TUFTE ER, 1990, ENVISIONING INFORMAT WOS \\
\hline & OLSEN KA, 1993, INFORM PROCESS MANAG, V29, P69 WOS \\
\hline & SHNEIDERMAN B, 1992, ACM T GRAPHIC, V11, P92 WoS \\
\hline & CARD S, 1999, READINGS INFORMATION WOS \\
\hline & DIBATTISTA G, 1994, COMP GEOM-THEOR APPL, V4, P235 WOS \\
\hline & FURNAS GW, 1986, P SIGCHI86, P16 WoS \\
\hline & WARE C, 2000, INFORMATION VISUALZ WOS \\
\hline & WISE JA, 1995, P IEEE S INF VIS 95, P51 WoS \\
\hline & FRUCHTERMAN TM], 1991, SOFTWARE PRACT EXPER, V21, P1.129 WoS \\
\hline & AHLBERG C, 1994, P ACM C HUM FACT COM, P313 WOS \\
\hline & EADES P, 1984, C NUMMERANTIUM, V42, P149 WOS \\
\hline & CARD SK, 1991, P CHI 91 HUMAN FACTO, P181 WoS \\
\hline & HENDLEY RJ, 1995, P 1995 INF VIS S ATL, P90 WOS \\
\hline & FAIRCHILD KM, 1988, COGNITIVE SCI ITS AP, P201 WOS \\
\hline & MISUE K, 1995 , J VISUAL LANG COMPUT, V6, P183 WoS \\
\hline & TAMASSIA R, 1987, SIAM J COMPUT, V16, P421 WOS \\
\hline & REINGOLD EM, 1981, IEEE T SOFTWARE ENG, V7, P223 WoS \\
\hline & FAIRCHTLD KM, 1988, COGNITIVE SCI ITS AP WOS \\
\hline & TAMASSIA R, 1989, IEEE T CIRCUITS SYST, V36, P1230 WoS \\
\hline & TUFTE E, 1983, VISUAL DISPLAY QUANT WOS \\
\hline & RAO R, 1994, P ACM SIGCHI C HUM F, P318 WoS \\
\hline & TUFTE E, 1990, ENVISIONING INFORMAT WOS \\
\hline & SHNEIDERMAN B, 1997, DESIGNING USER INTER WoS \\
\hline & LIN X, 1997, J AM SOC INFORM SCI, V48, P40 WoS \\
\hline & CHEN C, 1999, INFORMATION VISUALIS WOS \\
\hline & HEARST M, 1995, P CHI 95, P59 WoS \\
\hline & DIBATTISTA G, 1997, COMP GEOM-THEOR APPL, V7, P303 WoS \\
\hline
\end{tabular}

FIG. 27. Outer references for inform* visuali*.

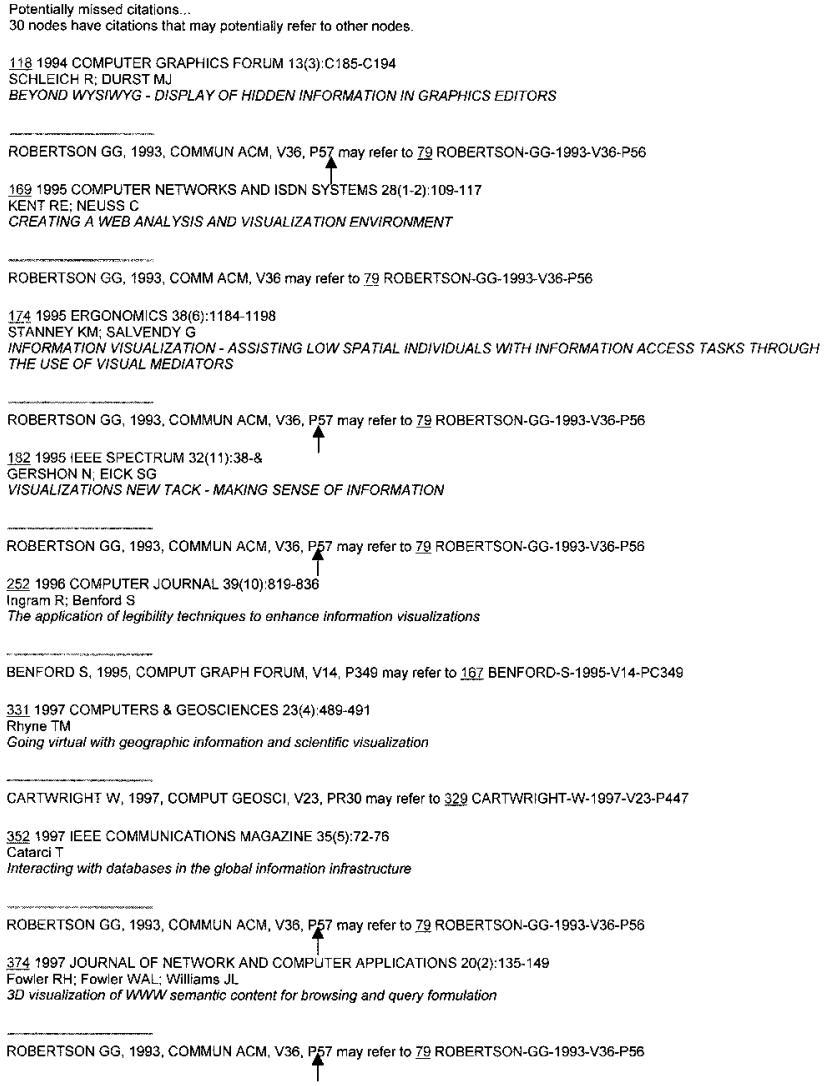

FIG. 28. Potential pagination errors in citations to Robertson 1963 paper.

56. Figure 28 shows that the "missing links" feature of our software questioned the pagination for this paper. Did Schleich (\#118) in 1994 incorrectly cite page 57? Did Kent \#169, Stanney \#174, and Gershon \#182 repeat the error? By going back into the $W o S$ it was determined that there were only about 20 cited references to page 56 but about 60 to page 57. Upon examining the original journal it was seen that page 56 was a blank page. The article really began on page 57. ISI has recently corrected this error-originally made back in 1993.

In conclusion, we have demonstrated how HistCite has aided the task of preparing historiographic accounts of topics, especially for the last half of the 20th century. But the process has equal validity in dealing with even more contemporary files and can give the user a snapshot of the key literature of any current topic. Whether by general keyword or by cited reference search, the method identifies the key works and permits their presentation in a traditional chronologic chart or as a more easily understood visual, genealogic chart. The process aids in identifying and correcting the many errors and variations that invariably occur in the literature.

\section{References}

Garfield, E. (2001a). "From computational liguinistics to algorithmic historigraphy." Lazerow Lecture held in conjunction with panel on "Knowledge and Language: Building large-scale knowledge bases for 
intelligent applications," presented at the University of Pittsburgh on September 19, 2001. Available: http://garfield.library.upenn.edu/papers/ pittsburgh92001.pdf.

Garfield, E. (2001b). From bibliographic coupling to co-citation analysis via algorithmic historio-bibliography: A citationist's tribute to Belver C. Griffith, Lazerow Lecture presented at Drexel University, Philadelphia, PA. November 27, 2001. Available: http://garfield.library.upenn.edu/ papers/drexelbevergriffith92001.pdf.

Garfield, E., Pudovkin A.I., \& Istomin, V.S. (2002). Algorithmic citation-linked historiography-Mapping the literature of science. Proceedings of the American Society for Information Science and Technology, 39:14-24, Annual Meeting, November 2002.

Garfield, E., Sher, I.H. , \& Torpie, R.H. (1964). The use of citation data in writing the history of science. Philadelphia: The Institute for Scientific Information, Report of research for Air Force Office of Scientific Research under contract F49(638)-1256. Available: http://www.garfield. library.upenn.edu/papers/useofcitdatawritinghistofsci.pdf.

Kessler, M.M. (1963). Bibliographic coupling between scientific papers. American Documentation, 14, 10+.

Lander, E.S., et al. (2001). Initial sequencing and analysis of the human genome. Nature, 408, 860-921.

Lowry, O.H., Rosebrough, N.J., Farr, A.L., \& Randall, R.J. (1951). Protein measurement with the Folin phenol reagent. Journal of Biological Chemistry, 193, 265-275.

Venter, J.C., et al. (2001). The sequence of the human genome. Science, $291,1304-1351$ 